Available online at GSC Online Press Directory

GSC Biological and Pharmaceutical Sciences

e-ISSN: 2581-3250, CODEN (USA): GBPSC2

Journal homepage: https://www.gsconlinepress.com/journals/gscbps

(RESEARCH ARTICLE)

\title{
Phytochemical estimations and antihypoxic effect of ethanol leaf extract of Milicia excelsa (Moraceae) in mice
}

\author{
Akinpelu Lateef Abiola 1, 2, ${ }^{*}$, Olawuni Idowu Julius ${ }^{3}$, Ogundepo Gbenga Emmanuel ${ }^{3}$, Olayiwola Gbola ${ }^{4}$ and \\ Fajana Akibu 5 \\ 1 Department of Pharmacology and Toxicology, Dora Akunyili College of Pharmacy, Igbinedion University, Okada, Edo \\ State, Nigeria. \\ 2 Department of Pharmacology, Faculty of Pharmacy, Obafemi Awolowo University Ile-Ife, Osun State, Nigeria. \\ ${ }^{3}$ Department of Biochemistry, Faculty of Science, Obafemi Awolowo University Ile-Ife, Osun State, Nigeria. \\ ${ }^{4}$ Department of Clinical Pharmacy, Faculty of Pharmacy, Obafemi Awolowo University Ile-Ife, Osun State, Nigeria. \\ ${ }^{5}$ Department of Pharmacognosy, Dora Akunyili College of Pharmacy, Igbinedion University, Okada, Edo State, Nigeria
}

Publication history: Received on 20 January 2020; revised on 01 February 2020; accepted on 04 February 2020

Article DOI: https://doi.org/10.30574/gscbps.2020.10.2.0015

\begin{abstract}
Milicia excelsa (Moraceae) is used to treat mental illnesses, among other traditional uses in Africa, but no scientific supports for its use. Hence, this study investigated the antihypoxic potential of the ethanol leaf extract of Milicia excelsa in mice, as well as determined quantitatively the phytoconstituents present in the extract. Hypoxia was induced by sodium nitrite (360 mg/kg, i.p., a haemic hypoxic model) and sodium fluoride (150 mg/kg, i.p., a circulatory hypoxic model) in mice. The phytocompounds were estimated using standard methods. The extract at 500 and $1000 \mathrm{mg} / \mathrm{kg}$, per oral significantly $(\mathrm{p}<0.05)$ prolonged the death latency in the haemic hypoxic mouse model while the extract at all the doses $(250,500$ and $1000 \mathrm{mg} / \mathrm{kg}$, p.o.) significantly $(\mathrm{p}<0.05)$ prolonged the death latency in the circulatory hypoxic mouse model suggesting antihypoxic effect. Total alkaloid was the most abundant of the phytochemicals assayed. This study therefore, concluded that the extract has an antihypoxic effect. The observed antihypoxic effect might be due to the abundance of total alkaloids which may either in synergy or additive with other plant secondary metabolites in the extract be responsible for the observed effect.
\end{abstract}

Keywords: Milicia excelsa leaf extract; Haemic hypoxia; Circulatory hypoxia; Total alkaloids.

\section{Introduction}

Hypoxia according to an earlier definition is the inadequate supply of oxygen to the body tissues, which can result in impairment of body functions and may cause an array of physiological aberration [1]. Hypoxia-induced neurodegeneration is one of the prime pathological states in clinical practice [2]. Low level of oxygen (hypoxia) is also associated with the pathologies of stroke [3] and medicinal plants with antihypoxic effects have been suggested to be suitable candidate for the treatment of stroke [2]. The most common symptom caused by hypoxia is acute mountain sickness (AMS) or counter high altitude sickness which often occurs when people travel to high altitudes [4]. Acetazolamide is the only drug approved by the United States Food and Drug Administration to attenuate AMS, but with numerous side effects [5].

Milicia excelsa (welw.) C.C. Berg also known as Chlorophora excelsa belongs to the family Moraceae popularly known as Iroko tree or African teak in Africa traditional medicine is a large deciduous tree 30 to $50 \mathrm{~m}$ high occurring naturally in

\footnotetext{
${ }^{*}$ Corresponding author

E-mail address: akinpelu_abiola01@yahoo.com
}

Copyright (C) 2020 Author(s) retain the copyright of this article. This article is published under the terms of the Creative Commons Attribution Liscense 4.0. 
humid forests of West Africa [6]. Its latex, leaf, stem bark, root, fruit, and ashes are used in African traditional medicine to treat malaria [7], mental illnesses [8], sexual dysfunction [9], and rheumatism [10] among other remedial uses. The antibacterial [11] [12], anti-amoebic [13], wound healing [14], antipsychotic [15], anti-stress [16] anticonvulsant [17], anti-amnesic and cognitive enhancing effects [18] of the plant have been reported. Ursolic acid and lupeol acetate are among the isolated compounds from the leaf of Milicia excelsa [19]. This study was designed to investigate the antihypoxic effects of the ethanol leaf extract of Milicia excelsa in mice, to provide a scientific basis for the ethnomedicinal uses of the leaf in the management of various brain-related disorders.

\section{Material and methods}

\subsection{Plant identification and authentication}

Milicia excelsa leaves were collected within the campus of the Obafemi Awolowo University (OAU). It was identified and authenticated by Mr. G. A. Ademoriyo of the Herbarium Unit, Department of Botany, Faculty of Science, OAU, Ile-Ife and herbarium number Ife 17482 was obtained.

\subsection{Preparation of the plant extract}

The leaves of Milicia excelsa plant were air-dried for two weeks at room temperature. The air-dried leaves were ground into powder and $1 \mathrm{~kg}$ of the powder was extracted with 3 liters of seventy percent (70\%) ethanol for $72 \mathrm{~h}$. The marc was re-extracted once and the combined extract was concentrated in vacuo at a temperature of $40{ }^{\circ} \mathrm{C}$ to yield $70 \mathrm{~g}$ (7.0\%) coded EME. The EME was prepared by dissolving with $2 \%$ Tween 20 and made up to the required volume with normal saline before administration to mice [15].

\subsection{Animals}

The animals used for this experiment were male mice. All the animals were bred and housed in a well lit and aerated room in the Animal House, Faculty of Pharmacy, OAU, Ile-Ife. They were maintained under natural daylight/night conditions. All animals had free access to drinking water and a standard commercial diet (Guinea feeds brand, Bendel Feeds Nigeria). The animals were used in groups of four $(n=6)$ per dose of the plant extract, per drugs in the positive and negative controls.

\subsection{Chemicals and drugs}

Sodium nitrite, sodium fluoride (Meck, Germany), Tween 20 (Sigma Aldrich, St. Louis, Missouri, U.S.A.) and physiological saline (Unique Pharmaceutical Limited, Lagos, Nigeria) were used. EME was dissolved with 2\% Tween 20 and made up to the required volume with normal saline.

\subsection{Preliminary phytochemical quantifications}

Preliminary phytochemical quantifications of EME were performed as previously carried out: total alkaloids [20] [21], total phenol [22] [23], total flavonoids [24] [25] and tannin content [26] [27]. $n=3$.

\subsection{Anti-hypoxic activity}

\subsubsection{Haemic hypoxia}

Twenty four mice were randomised into 4 groups $(\mathrm{n}=6)$. Group 1 (Control group) was orally administered with $2 \%$ Tween 20 in normal saline $\left(10 \mathrm{~mL} / \mathrm{kg}\right.$, p.o.). Thirty minutes post oral ingestion of EME $\left(250,500 \mathrm{and} 1000 \mathrm{mg} \mathrm{kg}^{-1}\right)$, $\mathrm{NaNO}_{2}$ (360 mg kg-1) was intraperitoneally injected to each mouse. The latency in minutes before the evidence of hypoxia was recorded [28]. Antihypoxic potential of EME was expressed relative to the control group.

\subsubsection{Circulatory hypoxia}

Twenty four mice were randomized into 4 groups (n=6). Group 1 (Control group) was orally administered with 2\% Tween 20 in normal saline (10 mL/kg, p.o.). Thirty minutes post oral ingestion of EME (250, 500 and 1000 mg kg-1), $\mathrm{NaF}$ (150 mg kg-1) was intraperitoneally injected to each mouse. The latency in minutes to the evidence of hypoxia was recorded [29]. Antihypoxic potential of EME was expressed relative to the control group. 


\subsection{Statistical analysis}

Experimental results are expressed as mean \pm SD. The data were analyzed by an analysis of variance (ANOVA) followed by Dunnett's post hoc test. Results were considered significant at $\mathrm{p}<0.05$.

\section{Results}

\subsection{Results of quantitative phytochemical estimations of EME}

The results of phytochemical estimation of EME (Table 1) showed that EME total alkaloid $>$ total phenols $>$ tannin content $>$ total flavonoids. The result is presented in Table 1.

Table 1 Quantitative phytochemical analysis of ethanol leaf extract of M. excels

\begin{tabular}{ll}
\hline \multicolumn{1}{c}{ Content } & \multicolumn{1}{c}{ Concentration } \\
\hline Total alkaloid content & $144.02 \pm 1.62 \mathrm{mg}$ of AE/g of extract \\
Total phenols & $22.52 \pm 0.76 \mathrm{mg} \mathrm{GAE} / \mathrm{g}$ extract \\
Tannin content & $19.88 \pm 0.5 \mathrm{mg}$ of GAE $/ \mathrm{g}$ of extract \\
Total flavonoid content & $3.01 \pm 0.01 \mathrm{mg} \mathrm{QE} / \mathrm{g}$ extract \\
\hline
\end{tabular}

Values are means of triplicate determination \pm Standard deviation; where AE is atropine equivalent, GAE is gallic acid equivalent, $Q E$ is quercetin equivalent and $\mathrm{AE}$ is atropine equivalent respectively.

\subsection{Result of antihypoxic effect of EME on sodium nitrite haemic induced hypoxia}

EME at 500 and $1000 \mathrm{mg} / \mathrm{kg}$ significantly $(\mathrm{p}<0.05)$ prolonged the death latencies following sodium nitrite induced respiratory arrest, however, EME at $250 \mathrm{mg} / \mathrm{kg}$ was found to be insignificant to prolong latencies for death compared to control. The result is presented in Table 2.

\subsection{Results of antihypoxic effect of EME on sodium fluoride in circulatory induced hypoxia}

EME at all the doses used $(250,500$ and $1000 \mathrm{mg} / \mathrm{kg})$ significantly $(\mathrm{p}<0.05)$ prolonged the death latencies following sodium fluoride induced hypoxia. The result is presented in Table 2.

Table 2 Anti-hypoxic activity of EME in the different hypoxia models

\begin{tabular}{llll}
\hline Group & Doses $(\mathrm{mg} / \mathbf{k g})$ & Sodium nitrite test (mins) & Sodium fluoride test (mins) \\
\hline Control & $10 \mathrm{~mL} / \mathrm{kg}$ & $10.50 \pm 0.45$ & $8.74 \pm 0.55$ \\
EME & 250 & $11.12 \pm 0.41$ & $12.50 \pm 0.74^{*}$ \\
EME & 500 & $14.40 \pm 1.37^{*}$ & $13.12 \pm 0.76^{*}$ \\
EME & 1000 & $14.52 \pm 1.30^{*}$ & $12.50 \pm 0.45^{*}$ \\
\hline
\end{tabular}

Control is $2 \%$ Tween 20 . Each value represents mean \pm SEM of the reaction time. ${ }^{*} \mathrm{p}<0.05$ compared to control. (ANOVA, Dunnett's post hoc test). $\mathrm{n}=6$

\section{Discussion}

This study investigated the antihypoxic effect as well as the phytochemical estimations of ethanol leaf extract of $M i l i c i a$ excelsa (EME) in mice. The finding of this study showed that EME possesses antihypoxic and showed abundance of total alkaloids in the phytochemicals assayed.

An earlier investigation has reported the LD50 of EME to be greater than or equal to $5000 \mathrm{mg} / \mathrm{kg}$ and doses of 250,500 and $1000 \mathrm{mg} / \mathrm{kg}$ were used in an earlier report [15], hence, this study employed the earlier used doses for the evaluation of the antihypoxic potentials of EME.

The prolongation of the death latency in sodium nitrite-induced chemical hypoxia by EME suggests that EME may possess an antihypoxic effect. The extract may enhance the oxygen-carrying capacity in this hypoxic model since sodium nitrite caused hypoxia by the reduction in oxygen-carrying capacity resulting in respiratory arrest and death [30]. This finding is in agreement with earlier reports of medicinal plants that prolonged death latencies in sodium nitrite-induced chemical hypoxia model and were suggested to exhibit antihypoxic effects [31] [32]. 
Several research findings have shown that alkaloids isolated from medicinal plants protected against sodium nitriteinduced hypoxia in mice [33-35] and possessed analgesic activities [36]. For example, the protective effects of berberine (an isoquinoline alkaloid found in Berberis, Hydrastis Canadensis and Coptidis rhizoma plants) on acute hypoxia-induced by sodium nitrite in mice have been reported [33]. Likewise, the cerebroprotective effect of isolated harmine alkaloids extracts of seeds of Peganum harmala L. on sodium nitrite-induced hypoxia in mice has also been reported [34]. Since alkaloid is the most abundant phytochemical assayed in EME, it could therefore, be suggested to be responsible for the antihypoxic effect of EME in sodium nitrite-induced hypoxic model as observed in this study.

The prolongation of the death latency in sodium fluoride-induced hypoxia may suggest antihypoxic effects. Literature data affirm that the administration of sodium fluoride (a substance that induces circulatory hypoxia) increases the blood histamine content and decreases the oxygen-carrying capacity [37] thereby resulting in death.

Alkaloids from medicinal plants have been shown to improve cerebral blood flow [38-40]. For example, vinpocetine, a vinca alkaloid, obtained from the leaves of the Lesser Periwinkle (Vinca minor) plant has been demonstrated to improve cerebral blood flow [38-40] and improve resistance to hypoxia [41]. Interestingly, ursolic acid, a triterpenoid is one of the isolated compounds from the leaf of Milicia excelsa [19] and its neuroprotective role in cerebral ischemic stroke has been documented [42-44]. Therefore, ursolic acid, either in synergy or additive with alkaloids in EME may be responsible at least in part for the observed antihypoxic effects.

\section{Conclusion}

This study concludes that EME has an antihypoxic effect. The antihypoxic effect may at least be due to the abundance of total alkaloids which may either in synergy or additive with other phytoconstituents in the extract be responsible for the observed antihypoxic effect. This may therefore, make the extract a suitable candidate for the prevention and/or management of stroke as well as acute mountain sickness (AMS).

\section{Compliance with ethical standards}

\section{Acknowledgments}

The authors are greatly indebted to the Technologists in the Department of Pharmacology, Faculty of Pharmacy, Obafemi Awolowo University, Ile-Ife, during the course of the experiment at the Obafemi Awolowo University, Ile-Ife.

\section{Disclosure of conflict of interest}

The authors declare no conflict of interest.

\section{Statement of ethical approval}

This experiments were carried out in strict adherence to the internationally accepted principles for Laboratory Animal Use and Care (EEC Directive of 1986; 86/609/EEC) as being strictly ensured by the Postgraduate College, Obafemi Awolowo University vide approval with the registration number PHP 11/12/H/2766.

\section{References}

[1] Chen CJ, Wang WY, Wang XL, Dong LW, Yue YT, Xin HL, Ling CQ and Li M. (2009). Anti-hypoxic activity of the ethanol extract from Portulaca oleracea in mice. Journal of Ethnopharmacology, 124, 246-250.

[2] Vyawahare NS and Ambikar DB. (2010). Evaluation of neuropharmacological activity of hydroalcoholic extract of fruits of Trapa bispinosa in laboratory animals. International Journal of Pharmacy and Pharmaceutical Sciences, 2(2), 32-35.

[3] Simon MC, Liu L, Barnhart BC, Regina M and Young RM. (2008). Hypoxia-induced signaling in the cardiovascular system. Annual Review of Physiology, 70, 51-71.

[4] Taylor AT. (2011). High-Altitude Illnesses: Physiology, Risk Factors, Prevention, and Treatment. Rambam Maimonides Medical Journal, 2(1), e0022.

[5] Clarke C. (2006). Acute mountain sickness: Medical problems associated with acute and subacute exposure to hypobaric hypoxia. Postgraduate Medical Journal, 82, 748-753. 
[6] Agyeman VK, Ofori DA, Cobbinah JR and Wagner MR. (2009). Influence of Phytolyma lata (Homoptera psyllidae) on seed growth of Milicia excelsa. Ghana Journal of Forestry, 25, 29-39.

[7] Titanji VPK, Zofou D and Ngemenya MN. (2008). The antimalarial potential of medicinal plants used for the treatment of malaria in cameroonian folk medicine. African Journal of Traditional, Complementary and Alternative Medicine, 5(3), 302 - 321.

[8] Ibrahim JA, Muazzam IA, Jegede OF Kunle and JI Okogun. (2007). Ethno-medicinal plants and methods used by Gwandara tribe of Sabo Wuse in Niger State, Nigeria, to treat mental illness. African Journal of Traditional, Complementary and Alternative Medicine, 4, 211-8.

[9] Betti JL, Yongo OD, Mbomio DO, Iponga DM and Ngoye A. (2013). An ethnobotanical and floristical study of medicinal plants among the Baka Pygmies in the periphery of the Ipassa- Biosphere Reserve, Gabon. European Journal of Medicinal Plants, 3(2), 174-205.

[10] Ndah NR, Egbe AE, Bechem E, Asaha S, Yengo T, Chia EL and Eyenieh NM. (2013). Ethnobotanical study of commonly used medicinal plants of the Takamanda Rainforest South West, Cameroon. African Journal of Plant Science, 7(1), 21-34.

[11] Oliver BEP. (1986). Medicinal plants in tropical West Africa. University Press. Cambridge, 1-8.

[12] Padayachee T and Odhav B. (2013). Antimicrobial activity of plant phenols from Chlorophora excelsa and Virgilia oroboides. Africa Journal of Biotechnology, 12, 2254-2261.

[13] Padayachee T and Odhav B. (2001). Anti-amoebic activity of plant compounds from Virgilia oroboides and Chlorophora excelsa. Journal of Ethnopharmacology, 78(1), 59-66.

[14] Udegbunam SO, Nnaji TO, Udegbunam RI, Okafor JC and Agbo I. (2013). Evaluation of herbal ointment formulation of Milicia excelsa (Welw) C.C berg for wound healing. African Journal of Biotechnology, 12(21), 3351-3359.

[15] Akinpelu LA, Akanmu MA and Obuotor EM (2018). Antipsychotic effects of ethanol leaf extract and fractions of Milicia excelsa (Moraceae) in mice. Journal of Pharmaceutical Research International, 22(6), 1-10.

[16] Akinpelu LA, Aiyelero OM and Olayiwola G. (2019). Ethanol leaf extract of Milicia excelsa mitigates anxiety and depressive-like behaviours induced by acute restraint stress in mice. GSC Biological and Pharmaceutical Sciences, $6(2), 30-39$.

[17] Akinpelu LA, Akanmu MA and Obuotor EM. (2018). Mechanism of anticonvulsant effects of ethanol leaf extract and fractions of Milicia excelsa (Moraceae) in mice. Journal of Pharmaceutical Research International, 23(4), 111.

[18] Akinpelu LA, Aiyelero OM, Olawuni IJ, Ogundepo GE and Olayiwola G. (2019). Anti-amnesic and cognitive enhancing effects of ethanol leaf extract of Milicia excelsa (Moraceae) in mice. International Journal of Neuroscience and Behavioral Science, 7(1), 1-11.

[19] Ouete JL, Sandjo LP, Kapche DW, Yeboah SO, Mapitse R, Abegaz BM, Opatz T and Ngadjui BT. (2014). Excelsoside: A new benzylic diglycoside from the leaves of Milicia excelsa. Zeitschrift für Naturforschung C, 69(7-8), 271-275.

[20] Shamsa F, Monsef H, Ghamooshi R and Verdian-rizi M. (2003). Spectrophotometric determination of total alkaloids in some Iranian medicinal plants. Thailand Journal of Pharmaceutical Sciences, 32, 17-20.

[21] Rao TM, Rao BG and Rao YV. (2012). Antioxidant activity of Spilanthes acmella extracts. International Journal of Phytopharmacology, 3(2), 216-220.

[22] Siddhuraju P and Becker K. (2003). Antioxidant properties of various solvent extracts of total phenolic constituents from three different agroclimatic origins of drumstick tree (Moringa oleifera Lam.) leaves. Journal of Agricultural and Food Chemistry, 51(8), 2144-2155.

[23] Gulcin I, Kufrevioglu OI, Oktay M and Buyukokuroglu ME. (2004). Antioxidant, antimicrobial, antiulcer and analgesic activities of nettle (Urtica dioica L.) Journal of Ethnopharmacology, 90, 205-15.

[24] Zhishen J, Mengcheng T and Jianming W. (1999). The determination of flavonoid contents in mulberry and their scavenging effects on superoxide radicals. Food Chemistry, 64(4), 555-559.

[25] Miliauskas G, Venskutonis PR and van Beek TA. (2004). Screening of radical scavenging activity of some medicinal and aromatic plant extracts. Food Chemistry, 85(2), 231-237. 
[26] AfifyAel-M, El-Beltagi HS, El-Salam SM and Omran AA. (2012). Biochemical changes in phenols, flavonoids, tannins, vitamin E, $\beta$-carotene and antioxidant activity during soaking of three white sorghum varieties. Asian Pacific Journal of Tropical Biomedicine, 2(3), 203-9.

[27] Singh K, Singh N, Chandy A and Manigauha A. (2012). In-vivo antioxidant and hepatoprotective activity of methanolic extracts of Daucus carota seeds in experimental animals. Asian Pacific Journal of Tropical Biomedicine, 2(5), 385-388.

[28] Roshtina L and Ostrovskaya R. (1981). Effect of piracetam on the body resistance to hypoxia. Farmakologiia Toksikologiia, 44, 210-213.

[29] Krasteva I, Nikolov I, Danchev N and Nikolov S. (2004). Phytochemical analysis of ethyl acetate extract from Astragalus corniculatus Bieb and brain antihypoxic activity. Acta Pharmaceutica, 54, 151-156.

[30] Ambikar DB and Mohanta GP. (2014). Evaluation of neuropharmacological activity of petroleum ether, methanolic and aqueous extracts of flower heads of Sphaeranthus indicus in mice. Journal of Applied Pharmaceutical Sciences, 4(04), 112-118.

[31] Ebrahimzadeh MA, Nabavi SF, Nabavi SM, Mahmoudi M, Eslami B and Dehpour AA. (2010). Biological and pharmacological effects of Delphinium elbursense. African Journal of Biotechnology, 9(34), 5542-5549.

[32] Yazdanpanah M, Mousavi Z and Ebrahimzadeh MA. (2016).Protective effects of Vicia hirsuta against hypoxiainduced lethality in mice. International Journal of Life Science and Pharma Research, 6(4), 17-21.

[33] Fan WJ, Lits and Tian YT. (2007). Protective effects of berberine on acute hypoxia induced by sodium nitrite in mice. Chinese Journal of Rehabilitation Theory Practice, 13, 704-705.

[34] Biradar SM, Joshi H and Tarak KC. (2013). Cerebroprotective effect of isolated harmine alkaloids extracts of seeds of Peganum harmala L. on sodium nitrite-induced hypoxia and ethanol-induced neurodegeneration in young mice. Pakistan Journal of Biological Sciences, 16(23), 1687-97.

[35] Ye M, Fu S, Pi R and He F. (2009). Neuropharmacological and pharmacokinetic properties of berberine: a review of recent research. Journal of Pharmacy and Pharmacology, 61(7), 831-7.

[36] Farouk L, Laroubi A, Aboufatima R, Benharref A and Chait A. (2008). Evaluation of the analgesic effect of alkaloid extract of Peganum harmala L.: Possible mechanisms involved. Journal of Ethnopharmacology, 115(3), 449-454.

[37] Sumina EN, Shugaev VA and Shugaev VA. (1978). The mechanism of circulatory hypoxia in acute with sodium fluoride poisoning. Farmakologiia Toksikologiia, 41(4), 480-482.

[38] Kiss B and Kárpáti E. (1996). Mechanism of action of vinpocetine. Acta Pharmaceutica Hungarica, 66(5), $213-24$.

[39] Kuzuya F. (1982). Effects of vinpocetine on platelet aggregability and erythrocyte deformability. European Geriatric Medicine, 20, 151-156.

[40] Kohlmeyer K. (1977). Zur Wirkung von Vincamin auf die Gehirdurchblutung des Menschen im Akutversuch. Arznein-Forsch., (Drug Res), 27(6A), 1285-1290.

[41] Erdo SL, Ning-Sheng C, Wolff JR and Kiss B. (1990). Vinpocetine protects against excitotoxic cell death in primary cultures of rat cerebral cortex. European Journal of Pharmacology, 187, 551-553.

[42] Li L, Zhang X, Cui L, Wang L, Liu H, Ji H and Du Y. (2013). Ursolic acid promotes the neuroprotection by activating Nrf2 pathway after cerebral ischemia in mice. Brain Research, 25(1497), 32-9.

[43] Wang Y, He Z and Deng S. (2016). Ursolic acid reduces the metalloprotease/anti-metalloprotease imbalance in cerebral ischemia and reperfusion injury. Drug Design, Development and Therapy, 10, 1663-1674.

[44] Wang Y, Li L, Deng S, Liu F and He Z. (2018). Ursolic Acid ameliorates inflammation in cerebral ischemia and reperfusion injury possibly via high mobility group box 1/Toll-Like Receptor 4/NFkB Pathway. Frontiers in Neurology, 9, 253.

\section{How to cite this article}

Akinpelu LA, Olawuni IJ, Ogundepo GE, Olayiwola G and Fajana A. (2020). Phytochemical estimations and antihypoxic effect of ethanol leaf extract of Milicia excelsa (Moraceae) in mice. GSC Biological and Pharmaceutical Sciences, 10(2), 24-29. 